\title{
Resistance of Xanthomonas euvesicatoria strains from Brazilian pepper to copper and zinc sulfates
}

\author{
MAYSA S. AREAS ${ }^{1}$, RICARDO M. GONÇALVES ${ }^{2}$, JOSÉ M. SOMAN ${ }^{1}$, RONALDO C. SOUZA FILHO ${ }^{1}$, \\ RICARDO GIORIA ${ }^{3}$, TADEU A.F. DA SILVA JUNIOR ${ }^{4}$ and ANTONIO C. MARINGONI ${ }^{1}$

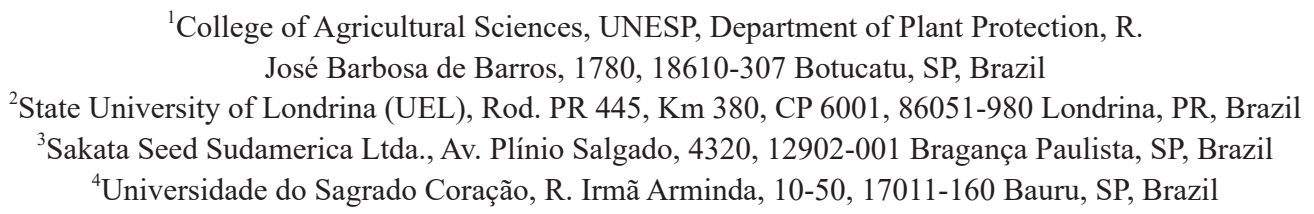

Manuscript received on July 5, 2016; accepted for publication on April 9, 2017

\begin{abstract}
Bacterial spot, caused by Xanthomonas spp., is one of the major bacterial diseases in pepper (Capsicum annuит L.). The infection results in reduced crop yield, particularly during periods of high rainfall and temperature, due to the low efficiency of chemical control with copper bactericides. This study evaluated the copper and zinc sulfate sensitivity of 59 pathogenic strains of Xanthomonas euvesicatoria isolated from pepper plants produced in various regions throughout Brazil. Both the respective sulfates and a mixture thereof was evaluated at 50,100, 200 and $400 \mu \mathrm{g} \cdot \mathrm{mL}^{-1}$. All the evaluated strains were found to be resistant to zinc sulfate $\left(100 \mu \mathrm{g} \cdot \mathrm{mL}^{-1}\right)$ and $86.4 \%$ were resistant to copper sulfate $\left(200 \mu \mathrm{g} \cdot \mathrm{mL}^{-1}\right)$. The mixture of copper $\left(200 \mu \mathrm{g} \cdot \mathrm{mL}^{-1}\right)$ and zinc $\left(200 \mu \mathrm{g} . \mathrm{mL}^{-1}\right)$ sulfates inhibited the growth of all strains of X. euvesicatoria. To our knowledge this is the first study to report the resistance of $X$. euvesicatoria strains from pepper plants to copper and zinc sulfates in Brazil.
\end{abstract}

Key words: Bacterial spot, Capsicum annuum, chemical sensitivity, control.

\section{INTRODUCTION}

Pepper plants (Capsicum annuum L.) are cultivated around the world and contain compounds that add flavor and aroma to foods, in addition to being a valuable source of vitamins (Fontes 2005). In the 2013 season, 472,526 tons of peppers were produced worldwide, and Brazil was responsible for the production of 42,312 tons (FAOSTAT 2016).

Correspondence to: Antonio Carlos Maringoni

E-mail: maringoni@fca.unesp.br

* Contribution to the centenary of the Brazilian Academy of Sciences.
Bacterial spot disease, caused by Xanthomonas euvesicatoria, $X$. vesicatoria, $X$. perforans and $X$. gardneri, is detrimental to pepper and tomato crops in several regions of the world, particularly during seasons of high rainfall and temperature (QuezadoDurval and Lopes 2010, Osdaghi et al. 2016, Potnis et al. 2015). X. euvesicatoria (Areas et al. 2015) and $X$. perforans (Araújo et al. 2017) are the major etiological agents causing bacterial spot in pepper and tomato crops, respectively, in Brazil.

Bacterial spot is very difficult to control due to the high pathogen variability and low efficiency of 
chemicals. Also, the efficiency of chemical control varies with the region, season and the intensity and frequency of spraying (Carmo et al. 2001). In Brazil, copper hydroxide and copper sulfate are currently registered for use as chemical agents to control bacterial spot in pepper crops (Agrofit 2016).

The first report of copper resistance in Xanthomonas spp. from pepper was reported in Florida, USA (Marco and Stall 1983). In Brazil, Maringoni and Kimati (1987a) reported a low in vitro sensitivity of Xanthomonas spp. from pepper and tomato plants to copper sulfate, copper oxychloride and copper hydroxide at $100 \mu \mathrm{g} \cdot \mathrm{mL}^{-1}$. However, these bacterial strains were sensitive to mixtures of copper and dithiocarbamate fungicides, suggesting a synergism between these chemicals.

Carmo et al. (2001) evaluated the effect of weekly spraying with copper oxychloride on the progress of bacterial spot infection in pepper plants in Brazil and observed varying efficiency. In most instances, the chemicals were found to be inefficient, particularly in environmental conditions favorable for disease development. Another study from Brazil by Aguiar et al. (2003), evaluated the effect of spraying copper sulfate, copper oxychloride, cuprous oxide and a mixture of cuprous oxide and mancozeb, on the control of bacterial spot infection in pepper plants. They reported that spraying with either copper oxide alone or in combination with mancozeb, reduced the epiphytic population of Xanthomonas spp., and controlled the disease to a satisfactory level.

Martin and Hamilton (2004) reported Xanthomonas spp. strains that were resistant to copper sulfate in pepper crops in Australia. More recently, Araújo et al. (2012) compared their results with those of Ritchie and Dittapongpitch (1991), and Quezado-Duval et al. (2003) finding that the level of copper sulfate-resistant Xanthomonas spp. in Brazilian tomato strains was lower than that detected in the USA.
Resistance to copper fungicides occurs due to continuous spraying of crops with copper chemicals, which results in the selective pressure of resistant bacteria (Martin and Hamilton 2004). Xanthomonas spp. from pepper plants may possess copper-resistant genes, which can be located in plasmids and transferred via conjugation to sensitive strains, resulting in these strains becoming resistant (Stall et al. 1986).

This study aimed to evaluate the in vitro sensitivity of $59 X$. euvesicatoria strains obtained from peppers produced throughout several regions of Brazil, to copper sulfate, zinc sulfate and mixtures thereof. The results presented herein will be important for improving the management of bacterial spot infection in pepper crops in Brazil.

\section{MATERIALS AND METHODS}

\section{STRAINS OF Xanthomonas euvesicatoria}

We used $59 X$. euvesicatoria strains isolated from the leaves of pepper plants showing symptoms of bacterial spot from several locations in Brazil (Table I). These bacterial strains are the same as those used by Areas et al. (2015) that were identified by PCR and physiological features by these authors.

\section{PATHOGENICITY TEST}

Pepper plants (cv. Early California Wonder) were grown in $3 \mathrm{~L}$ plastic pots with substrate (sand, ravine clay soil and the commercial substrate Bioplant ${ }^{\circledR}$ at a ratio of $\left.1: 1: 1\right)$ under greenhouse conditions $\left(20-30^{\circ} \mathrm{C}\right.$ and $\left.70-90 \% \mathrm{RH}\right)$. The plants were inoculated with $X$. euvesicatoria six weeks after sowing. All bacterial strains used for the inoculation had been grown in NSA medium (Dinghra and Sinclair 1995). The colonies were suspended in sterile distilled water and the bacterial suspensions were standardized by turbidity $\left(\mathrm{OD}_{600 \mathrm{~mm}}\right.$ $=0.1)$ to $10^{8} \mathrm{CFU} \cdot \mathrm{mL}^{-1}$. Four pepper plants were inoculated per bacterial strain, using the syringe infiltration method (two leaves per pepper plant). 
TABLE I

Xanthomonas euvesicatoria strains from pepper evaluated in this study.

\begin{tabular}{|c|c|}
\hline Location/State & Strain \\
\hline Apodi/Rio Grande do Norte (RN)* & Xcv 255/Xcv 256/Xcv 257/Xcv 258/Xcv 259 \\
\hline Bacuriti/ Sao Paulo (SP)* & Xcv 214/Xcv 215/Xcv 216/Xcv 218/Xcv 219 \\
\hline Belém/Para (PA)* & Xcv 190/Xcv 191/Xcv 198/Xcv 199/Xcv 201/Xcv 202/Xcv 207/Xcv 209 \\
\hline Bertioga/Sao Paulo (SP)* & Xcv 81 \\
\hline Botucatu/ Sao Paulo (SP)* & Xcv 01 \\
\hline Bragança Paulista/ Sao Paulo (SP)* & Xcv 154/Xcv 157/Xcv 239 \\
\hline Brasília/Distrito Federal (DF)** & P-7 \\
\hline Campinas/ Sao Paulo (SP)* & Xcv 237 \\
\hline Cardeal/Sao Paulo (SP)* & Xcv 250/Xcv 251/Xcv 252/Xcv 253/Xcv 274 \\
\hline Elias Fausto/ Sao Paulo (SP)* & Xcv 93/Xcv 188/Xcv 238/Xcv 240/P-3 \\
\hline Ibiúna/ Sao Paulo (SP)* & Xcv 236 \\
\hline Lins/ Sao Paulo (SP)* & $\mathrm{Xcv} 02 / \mathrm{Xcv} 53 / \mathrm{Xcv} 54 / \mathrm{Xcv} 62 / \mathrm{Xcv} 70$ \\
\hline Mogi das Cruzes/ Sao Paulo (SP)* & Xcv 96/Xcv 97/Xcv 98 \\
\hline Nova Friburgo/Rio de Janeiro (RJ)** & $\mathrm{P}-1 / \mathrm{P}-13$ \\
\hline Piracicaba/ Sao Paulo (SP)** & $\mathrm{P}-14$ \\
\hline Pouso Alegre/Minas Gerais (MG)* & Xcv 231/Xcv 232/Xcv 233/Xcv 242/Xcv 249 \\
\hline São Miguel Aracanjo/ Sao Paulo (SP)* & Xcv 248/Xcv 261 \\
\hline Socorro/ Sao Paulo (SP)* & Xcv 263 \\
\hline Tinguá/Ceara $(\mathrm{CE})^{*}$ & Xcv 266/Xcv 287/Xcv 288/Xcv 289 \\
\hline
\end{tabular}

*Sakata Seed Sudamérica, Brazil;

**FCA/UNESP, Brazil.

Bacterial spot symptoms were assessed ten days after inoculation (Maringoni and Kimati 1987b).

In vitro ASSAY

The growth of all the evaluated strains was assessed for sensitivity to copper sulfate (Sigma-Aldrich Co., USA), zinc sulfate (Ecibra Co., Brazil), and mixtures thereof $(50 \%$ each) at $0,50,100,200$ and $400 \mu \mathrm{g} \cdot \mathrm{mL}^{-1}$. The evaluated concentrations of sulfates were similar to those used by Ritchie and Dittapongpitch (1991), Gore and O'Garro (1999), Costa et al. (2012) and Osdaghi et al. (2016). The copper and zinc sulfates were dissolved in distilled and sterilized water and then added to the sterilized PSA medium (Dinghra and Sinclair 1995) in a melted state at $50^{\circ} \mathrm{C}$, to obtain the desired concentrations. PSA medium without added sulfates was used as a control. PSA medium was selected as it has been used previously in assays developed by Ritchie and Dittapongpitch (1991), Gore and O'Garro (1999) and Mirik et al. (2007), for the same purpose.

All the studied bacterial strains were cultivated on NSA at $28^{\circ} \mathrm{C}$ for $48 \mathrm{~h}$. The bacterial suspensions were prepared in sterile distilled water and standardized by turbidity $\left(\mathrm{OD}_{600 \mathrm{~nm}}=0.1\right)$ to $10^{8}$ CFU. $\mathrm{mL}^{-1}$. Aliquots $(10 \mu \mathrm{L})$ were then seeded onto four equidistant points on the surface of the PSA medium. The plates were incubated at $28^{\circ} \mathrm{C}$ for 24 $\mathrm{h}$, and presence (insensitive) or absence (sensitive) of bacterial growth was recorded. Five replicates were performed for each strain and at each chemical concentration. 


\section{RESULTS AND DISCUSSION}

All the evaluated $X$. euvesicatoria strains were pathogenic to pepper and insensitive to copper or zinc sulfates at 50 or $100 \mu \mathrm{g} \cdot \mathrm{mL}^{-1}$. At $200 \mu \mathrm{g} \cdot \mathrm{mL}^{-1}$ copper sulfate, $13.6 \%$ of the strains did not grow. Furthermore, the growth of $11.9 \%$ of the strains was inhibited at $200 \mu \mathrm{g} \cdot \mathrm{mL}^{-1}$ zinc sulfate. At 400 $\mu \mathrm{g} . \mathrm{mL}^{-1}$, the growth of 35.6 and $42.4 \%$ of the $X$. euvesicatoria strains was inhibited for copper and zinc sulfate, respectively. Treatment of the strains with a copper and zinc sulfates mixture showed increased sensitivity, with $3.4,49.2$ and $100 \%$ of the strains inhibited at 100, 200 and $400 \mu \mathrm{g} \cdot \mathrm{mL}^{-1}$, respectively (Figure 1).
Xanthomonas spp. from tomato and pepper plants have been shown to be resistant to copper and zinc sulfates when grown in a PSA medium containing 200 and $100 \mu \mathrm{g} . \mathrm{mL}^{-1}$ of these chemicals, respectively (Ritchie and Dittapongpitch 1991, Ward and O'Garro 1992, Gore and O'Garro 1999). The strains evaluated in this study were predominantly resistant to zinc sulfate $(100 \%)$ and copper sulfate $(86.4 \%)$. All strains collected from Apodi (RN), Tinguá (CE), Nova Friburgo (RJ) and Brasília (DF) were resistant to both copper and zinc sulfates, while over $80 \%$ of the strains from São Paulo (SP), Minas Gerais (MG) and Pará (PA) were resistant to copper sulfate (Table II). All the strains were resistant to zinc sulfate (Table II).

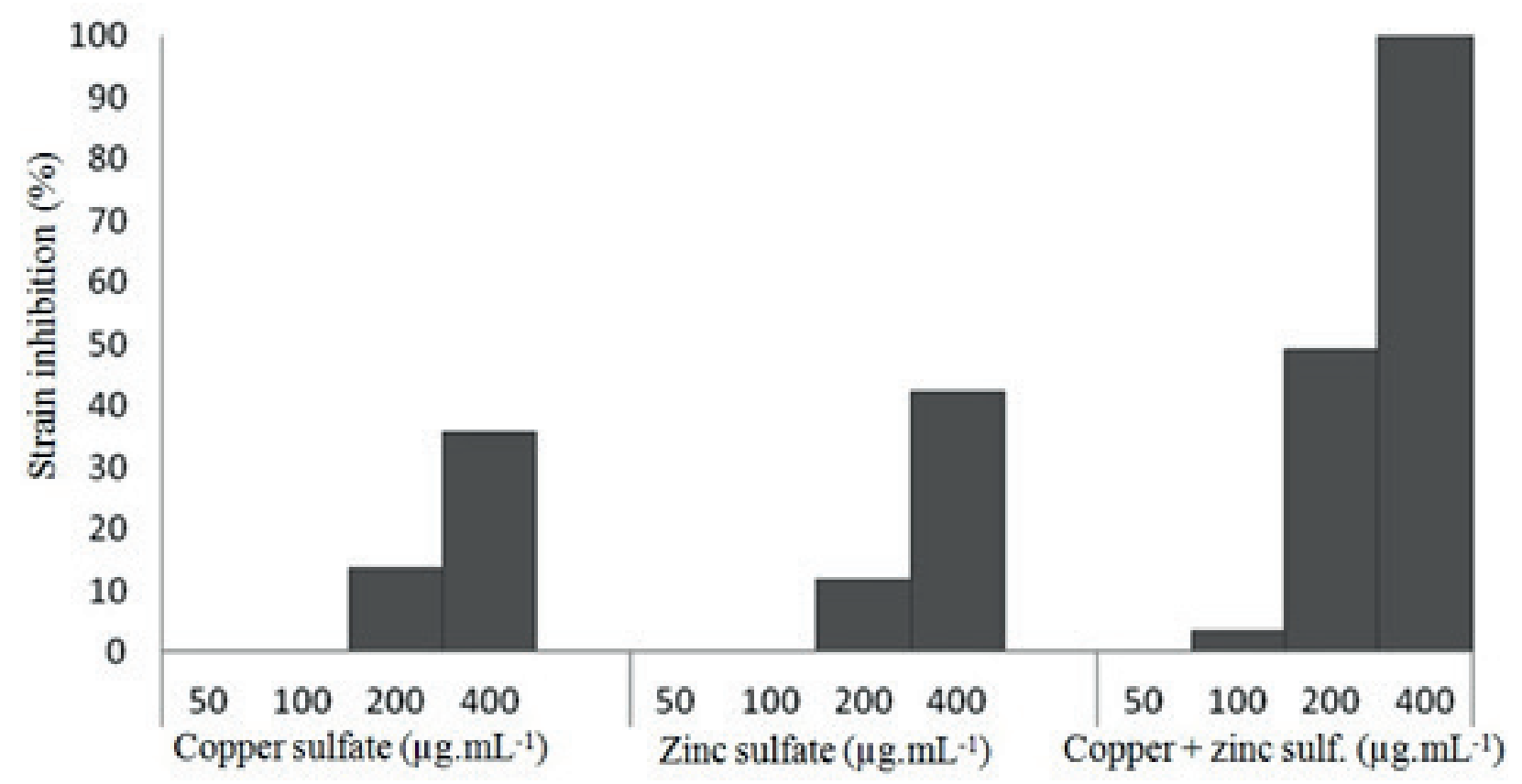

Figure 1 - In vitro sensitivity of Xanthomonas euvisatoria strains from pepper to copper sulfate, zinc sulfate and a mixture of copper and zinc sulfates. 
TABLE II

In vitro inhibition of Xanthomonas euvesicatoria strains from several locations in Brazil to copper sulfate, zinc sulfate and a mixture of copper and zinc sulfates.

\begin{tabular}{|c|c|c|c|c|c|c|c|c|}
\hline \multirow[b]{2}{*}{ Product } & \multirow{2}{*}{$\begin{array}{l}\text { Concentration } \\
\left(\mu \mathrm{g} \cdot \mathrm{mL}^{-1}\right)\end{array}$} & \multicolumn{7}{|c|}{ Strain/location } \\
\hline & & $\begin{array}{l}\text { State of Sao } \\
\text { Paulo }(34)^{a, b}\end{array}$ & $\begin{array}{l}\text { Belem/ } \\
\operatorname{PA}(8)^{a}\end{array}$ & $\begin{array}{l}\text { Pouso Alegre/ } \\
\text { MG (5) }\end{array}$ & $\begin{array}{l}\text { Apodi/ } \\
\text { RN (5) }\end{array}$ & $\begin{array}{l}\text { Tingua/ } \\
\text { CE (4) }\end{array}$ & $\begin{array}{c}\text { Nova Friburgo/ } \\
\text { RJ (2) }\end{array}$ & $\begin{array}{l}\text { Brasília/ } \\
\text { DF }(1)^{\mathrm{a}}\end{array}$ \\
\hline \multirow{4}{*}{$\begin{array}{l}\text { Copper } \\
\text { sulfate }\end{array}$} & 50 & $0^{\mathrm{c}}$ & 0 & 0 & 0 & 0 & 0 & 0 \\
\hline & 100 & 0 & 0 & 0 & 0 & 0 & 0 & 0 \\
\hline & 200 & 17.65 & 12.25 & 12.5 & 0 & 0 & 0 & 0 \\
\hline & 400 & 41.18 & 25 & 40 & 0 & 50 & 50 & 0 \\
\hline \multirow{4}{*}{ Zinc sulfate } & 50 & 0 & 0 & 0 & 0 & 0 & 0 & 0 \\
\hline & 100 & 0 & 0 & 0 & 0 & 0 & 0 & 0 \\
\hline & 200 & 11.76 & 12.5 & 12.5 & 0 & 25 & 0 & 0 \\
\hline & 400 & 38.24 & 25 & 80 & 40 & 75 & 0 & 0 \\
\hline \multirow{4}{*}{$\begin{array}{l}\text { Copper }+ \\
\text { zinc sulfates }^{\mathrm{d}}\end{array}$} & 50 & 0 & 0 & 0 & 0 & 0 & 0 & 0 \\
\hline & 100 & 5.88 & 0 & 0 & 0 & 0 & 0 & 0 \\
\hline & 200 & 35.29 & 50 & 60 & 40 & 50 & 0 & 0 \\
\hline & 400 & 100 & 100 & 100 & 100 & 100 & 100 & 100 \\
\hline
\end{tabular}

${ }^{\mathrm{a}}$ Number of strains analyzed; ${ }^{\mathrm{b}}$ Several localities; ${ }^{\mathrm{c}}$ Percentage inhibition; ${ }^{\mathrm{d}}$ Mixture containing $50 \%$ of copper and $50 \%$ of zinc sulfates.

The high percentage of $X$. euvesicatoria strains resistant to copper sulfate is due to the intensive use of copper fungicides for the control of bacterial spot over many years, which has resulted in the selection of strains resistant to copper (Ritchie and Dittapongpitch 1991, Ward and O'Garro 1992, Gore and O'Garro 1999, Aguiar et al. 2000).

Several studies have previously investigated the in vitro sensitivity and resistance, or both, of Xanthomonas spp. from tomato and pepper plants to copper and zinc sulfates. Ward and O'Garro (1992) observed that 61 and $64 \%$ of Xanthomonas spp. from tomato and pepper plants were resistant to copper $\left(200 \mu \mathrm{g} \cdot \mathrm{mL}^{-1}\right)$ and zinc sulfates $(100$ $\left.\mu \mathrm{g} \cdot \mathrm{mL}^{-1}\right)$, respectively. Similar results were obtained by Ritchie and Dittapongpitch (1991), Gore and O'Garro (1999) and Costa et al. (2012), who observed that over $60 \%$ of Xanthomonas spp. from tomato and pepper plants were resistant to treatment with $200 \mu \mathrm{g} . \mathrm{mL}^{-1}$ copper sulfate.

$X$. euvesicatoria strains evaluated in our study were more sensitive to treatment with the copper and zinc sulfates mixture, than either chemical alone, due to synergism between these chemicals. Similar results were obtained by Maringoni and Kimati (1987a), using a mixture of cupric and thiocarbamate fungicides, which was found to inhibit the in vitro growth of Xanthomonas spp. obtained from pepper and tomato plants. Spraying of crops with mixtures of copper oxide and mancozeb fungicides has shown a good level of bacterial spot control in pepper plants (Aguiar et al. 2003). Thus, the use of fungicides containing both copper and thiocarbamates have been suggested for the management of bacterial spot on pepper plants in Brazil. To our knowledge this is the first study to investigate the resistance of $X$. euvesicatoria strains to copper and zinc sulfates obtained from pepper plants produced in various areas throughout Brazil.

\section{ACKNOWLEDGMENTS}

The authors thank the Coordenação de Aperfeiçoamento de Pessoal de Nível Superior 
(CAPES) for the granting of the Master's scholarship for the first author and Sakata Seed Sudamérica for the financial support and donation of Xanthomonas euvesicatoria strains.

\section{REFERENCES}

AGROFIT. 2016. Sistema de agrotóxicos fitossanitários. Avaliable at: http://agrofit.agricultura.gov.br/agrofit_cons/ principal_agrofit_cons. Accessed 03 June 2016.

AGUIAR LA, KIMURA O, CASTILHO AM, CASTILHO KSC, RIBEIRO RLD, AKIBA F AND CARMO MGF. 2000. Resistência ao cobre em isolados nacionais de Xanthomonas campestris pv. vesicatoria de pimentão e tomateiro. Agronomia 34: 78-82.

AGUIAR LA, KIMURA O, CASTILHO AMC, CASTILHO KSC, RIBEIRO RLD, AKIBA F AND CARMO MGF. 2003. Effect of copper formulations on resident Xanthomonas campestris pv. vesicatoria populations on sweet pepper leaf surfaces. Hortic Bras 21: 44-50.

ARAÚJO ER, PEREIRA RC, FERREIRA MASV, QUEZADO-DUVAL AM AND CAFÉ-FILHO AC. 2012. Sensitivity of xanthomonads causing tomato bacterial spot to copper and streptomycin and in vivo infra-specific competitive ability in Xanthomonas perforans resistant and sensitive to copper. J Plant Pathol 94: 79-87.

ARAÚJO ER, COSTA JR, FERREIRA MASV AND QUEZADO-DUVAL AM. 2017. Widespread distribution of Xanthomonas perforans and limited presence of $X$. gadneri in Brazil. Plant Pathol 66: 159-168.

AREAS MS, GONÇALVES RM, SOMAN JM, SILVA JC, SOUZA-FILHO RC, SILVA JUNIOR TAF, GIORIA R AND MARINGONI AC. 2015. Prevalence of Xanthomonas euvesicatoria on pepper in Brazil. J Phytopathol 163: 1050-1054.

CARMO MGF, MACAGNAN D AND CARVALHO AD. 2001. Progress of bacterial leaf spot of pepper starting with different initial quantities of infected seedlings and treatment with the use or not of copper oxichloride. Hortic Bras 19: 210-215.

COSTA JR, ARAÚJO ER, BECKER WF, FERREIRA MASV AND QUEZADO-DUVAL AM. 2012. Occurrence and characterization of the species complex causing tomato bacterial spot in "Alto Vale do Rio do Peixe", SC, Brazil. Trop Plant Pathol 37: 149-154.

DHINGRA OD AND SINCLAIR JB. 1995. Basic Plan Pathology Methods, $2^{\text {nd }}$ ed., CRS Press, Boca Raton.

FAOSTAT. 2016. Food and Agriculture Organization of the United Nations - Statistics Division. Avaliable at: http:// faostat3.fao.org/browse/Q/QC/E. Accessed: 9 June 2016.

FONTES PCR. 2005. Olericultura: Teoria e Prática, $1^{a}$ ed., Universidade Federal de Viçosa, Viçosa.
GORE JP AND O'GARRO LW. 1999. Reaction of Xanthomonas campestris from bell pepper and tomato in Barbados to chemical control agents. J Phytopathol 147: 397-402.

MARCO GM AND STALL RE. 1983. Control of bacterial spot of pepper initiated by strains of Xanthomonas campestris pv. vesicatoria that differ in sensitivity to copper. Plant Dis 67: 779-781.

MARINGONI AC AND KIMATI H. 1987a. In vitro sensitivity of Xanthomonas campestris pv. vesicatoria (Doidge) Dye from pepper and tomato to chemicals. Summa Phytopathol 13: $160-171$.

MARINGONI AC AND KIMATI H. 1987b. Pathogenic characterization and starch hydrolysis on Xanthomonas campestris pv. vesicatoria from pepper and tomato. Fitopatol Bras 12: 325-333.

MARTIN HL AND HAMILTON VA. 2004. Copper tolerance in Australian populations of Xanthomonas campestris pv. vesicatoria contributes to poor field control of bacterial spot of pepper. Plant Dis 88: 921-924.

MIRIK M, AYSAN Y AND CINAR O. 2007. Copper-resistant strains of Xanthomonas axonopodis pv. vesicatoria (Doidge) Dye in the eastern mediterranean region of Turkey. J Plant Pathol 89: 153-154.

OSDAGHI E, TAGHAVI SM, HAMZEHZARGHANI H AND LAMICHLANE JR. 2016. Occurrence and characterization of the bacterial spot pathogen Xanthomonas euvesicatoria on pepper in Iran. J Phytopathol 164: 722-734.

POTNIS N, TIMILSINA S, STRAYER A, SHANTHARAJ D, BARAK JD, PARET ML, VALLAD GE AND JONES JB. 2015. Bacterial spot of tomato and pepper: diverse Xanthomonas species with a wide variety of virulence factors posing a worldwide challenge. Mol Plant Pathol 16: $907-920$.

QUEZADO-DUVAL AM, GAZZOTO FILHO A, LEITE JÚNIOR RP AND CAMARGO LEA. 2003. Sensitivity to copper streptomycin and oxitetracyclin of xanthomonads associated to bacterial spot in processing tomatoes. Hortic Bras 21: 672-677.

QUEZADO-DUVAL AM AND LOPES CA. 2010. Mancha bacteriana: uma atualização para o sistema de produção integrada de tomate indústria. Embrapa Hortaliças. Brasília-DF. Circular Técnica 84.

RITCHIE DF AND DITTAPONGPITCH V. 1991. Copperand streptomycin-resistant strains and host differentiated races of Xanthomonas campestris pv. vesicatoria in North Carolina. Plant Dis 75: 733-736.

STALL RE, LOSCHKE DC AND JONES JB. 1986. Linkage of copper resistence and avirulence loci on a selftransmissible plasmid in Xanthomonas campestris pv. campestris. Phytopathology 76: 240-242.

WARD HP AND O'GARRO LW. 1992. Bacterial spot of pepper and tomato in Barbados. Plant Dis 76: 1046-1048. 